\title{
Anaerobic Co-digestion of the Energy Crop Sida hermaphrodita and Microalgae Biomass for Enhanced Biogas Production
}

\author{
M. Dębowski ${ }^{1}$ - M. Zieliński ${ }^{1}$ M. Kisielewska ${ }^{1}$ (D) M. Krzemieniewski ${ }^{1}$
}

Received: 8 February 2017/Revised: 11 May 2017/ Accepted: 23 May 2017/Published online: 29 May 2017

(C) The Author(s) 2017. This article is an open access publication

\begin{abstract}
This study presents the results of anaerobic codigestion of perennial crop Sida hermaphrodita and microalgae biomass under semi-continuous conditions. The aim of this study was to compare biogas potential from the silage of Sida mixed in different ratios with microalgal species of Chlorella sp. and Scenedesmus sp. The results showed that the co-digestion process improved biogas/ methane production to the level of $594.52 / 351.88 \mathrm{~mL} / \mathrm{g}$ volatile solids. The best results were achieved when microalgae biomass constituted 40 and $60 \%$ of the substrate, and $\mathrm{C} / \mathrm{N}$ ratio ranged from 14.69 to 20.61. The composition of digestates was also determined.
\end{abstract}

Keywords Perennial crop · Crop silage · Algae ·

Feedstock composition $\cdot$ Methane $\cdot \mathrm{C} / \mathrm{N}$ ratio

\section{Introduction}

Development of a sustainable bioenergy market is now based on energy crops that can substitute fossil resources (Barbosa et al. 2014). However, energy crop production on arable lands competes with global food and feed supply (Schwede et al. 2013; Jankowski et al. 2016). Consequently, there is a need for searching the non-food plant species to rebalance the support of bioenergy and biofuels versus food feedstock use. These plants should be characterized by high-yield, low-nutrient demand and valuable

M. Kisielewska

jedrzejewska@uwm.edu.pl

1 Department of Environmental Engineering, University of Warmia and Mazury in Olsztyn, Warszawska Str.117, 10-950 Olsztyn, Poland biological composition for a variety of bioeconomic applications to meet the idea of a low input-high output system (Jablonowski et al. 2016).

The perennial Sida (Sida hermaphrodita) offers a promising alternative to conventional energy crops for energy purposes (Borkowska and Molas 2012, 2013; Nabel et al. 2016). Sida has low requirements of soil conditions, and it grows on sandy and rocky soils with low organic matter content useless for feed or food production (Borkowska and Wardzinska 2003). Depending on the soil conditions, cultivation practices, the age of the plant and the frequency and harvesting time, Sida produces from 10 to $25 \mathrm{t} / \mathrm{ha}$ of dry matter, which is higher compared to currently used energy plants like corn (Borkowska and Molas 2013; Oleszek et al. 2013). Besides its high-yield biomass, Sida is also able to store carbon in a root system and sequester it underground for many years, contributing to greenhouse gas (GHG) mitigation (To et al. 2010). Presently, Sida is used as a solid fuel for combustion (Jablonowski et al. 2016). However, the experiments of anaerobic digestion (AD) of Sida have shown its great potential as a useful substrate for biogas production over $400 \mathrm{~L} / \mathrm{kg}$ (Oleszek et al. 2013; Pokój et al. 2015).

Algal biomass is another alternative to typical energy crops which may be produced independently of farmland. The algal biomass productivity is estimated at $100-150 \mathrm{t} /$ ha, which is $10-15$ times higher than the conventional agricultural crops (Chinnasamy et al. 2010). As energy feedstock, it can be transformed into many types of biofuels: biodiesel, biohydrogen, biogas or it may also be used for direct combustion (Pienkos and Darzins 2009; Dębowski et al. 2013). Literature data indicate that conversion of the algae biomass into biogas is a highly profitable solution and the obtained methane achieves 
140-360 $\mathrm{mL} / \mathrm{g}$ volatile solids (VS) depending on the algal species (Wang and Park 2015).

Anaerobic digestion (AD) is nowadays widely used to produce renewable energy from organic waste biomass (Montingelli et al. 2015). There are several factors which limit AD efficiency, i.e., the cell wall resistance to anaerobic digestion, cellulose or hemicellulose content in biomass, formation of toxic compounds for anaerobic bacteria, as well as an inappropriate $\mathrm{C} / \mathrm{N}$ ratio in the feedstock subjected to anaerobic reactors (Chynoweth et al. 1993; Mata-Alvarez et al. 2000; Yen and Brune 2007). The $\mathrm{C} / \mathrm{N}$ ratio in the feedstock for AD amounts to 20/1-30/1 (Parkin and Owen 1986). The $\mathrm{C} / \mathrm{N} / \mathrm{P}$ stoichiometry of terrestrial plants is determined by the balance of nutrient uptake for growth and can also be influenced by nutrient supply (Güsewell 2004; Peng et al. 2011; Barbosa et al. 2014). Thus, the availability of nutrients in soil contributes to the differences in $\mathrm{C} / \mathrm{N}$ in Sida, which may influence subsequent biogas production from harvested biomass. Moreover, the date of harvest and the parts of plant used as a biogas substrate also determine the biomass characteristics (Peng et al. 2011). In turn, the $\mathrm{C} / \mathrm{N}$ ratio of algae biomass is generally below 10 , which may cause a high concentration of ammonia nitrogen and volatile fatty acids in anaerobic reactors, leading to an inhibition of methanogenesis (Zhong et al. 2012; Dębowski et al. 2013).

The process of mixing different fermentation substrates, commonly known as co-digestion, generally enhances AD results. The main benefits of the co-digestion process are adjustment of the moisture content, $\mathrm{pH}$ and $\mathrm{C} / \mathrm{N}$ ratio, supply of buffer capacity, and dilution of toxic compounds, which consequently enhance biogas/methane production (Mata-Alvarez et al. 2000; Wu et al. 2010; Esposito et al. 2012). In this study we evaluated the biogas potential of Sida hermaphrodita (L.) Rusby with inappropriate $\mathrm{C} / \mathrm{N}$ content of 142.55. To improve the chemical properties of Sida as a biogas feedstock, it was mixed with microalgae in different ratios. The aim of the study was to investigate the potential of microalgae biomass as the feedstock for codigestion with energy crop Sida to enhance biogas/methane yield. As far as we know, it is the first time that energy crop Sida was co-digested with microalgae biomass.

\section{Materials and Methods}

\section{Biomass Materials}

Sida hermaphrodita (L.) Rusby was cultivated in the Research and Experimental Station in Łężany of the University of Warmia and Mazury in Olsztyn (Poland), $\left(53^{\circ} 96^{\prime} 67^{\prime \prime} \mathrm{N}, 21^{\circ} 13^{\prime} 33^{\prime \prime} \mathrm{E}\right)$. No fertilizers were applied for cultivation. Plants were harvested at $\mathrm{BBCH}-\mathrm{Sida}$ development stage 55 (June, 4th year of growing) by rowless maize chopper that chopped the crops into pieces of $10 \mathrm{~mm}$ in length. The freshly shredded biomass was subsequently ensiled in a horizontal silo with drainage for 16 weeks.

The algal biomass used in the study was obtained from our own culture collection. The previously isolated mixed cultures of Chlorella sp. and Scenedesmus sp. were cultivated photoautotrophically in a single, closed, vertical, tubular photobioreactor with an active volume of $50 \mathrm{~L}$ (inner diameter 200 and $1700 \mathrm{~mm}$ height) made of transparent plexiglass equipped with white light with reflector (700 1x, Osram, Germany). The culture medium composition was: $\mathrm{KH}_{2} \mathrm{PO}_{4} 17.5 \mathrm{~g} / \mathrm{L}, \mathrm{K}_{2} \mathrm{HPO}_{4} 7.5 \mathrm{~g} / \mathrm{L}, \mathrm{NaNO}_{3}$ $25 \mathrm{~g} / \mathrm{L}, \quad \mathrm{MgSO}_{4} \cdot 7 \mathrm{H}_{2} \mathrm{O} \quad 7.5 \mathrm{~g} / \mathrm{L}, \quad \mathrm{FeSO}_{4} \cdot 7 \mathrm{H}_{2} \mathrm{O} 5 \mathrm{~g} / \mathrm{L}$, $\mathrm{CaCl}_{2} \cdot 2 \mathrm{H}_{2} \mathrm{O} 2.5 \mathrm{~g} / \mathrm{L}, \mathrm{H}_{3} \mathrm{BO}_{3} 11.42 \mathrm{~g} / \mathrm{L}, \mathrm{MnCl}_{2} \cdot 4 \mathrm{H}_{2} \mathrm{O}$ $1.44 \mathrm{~g} / \mathrm{L}, \mathrm{ZnSO}_{4} \cdot 7 \mathrm{H}_{2} \mathrm{O} 8.82 \mathrm{~g} / \mathrm{L}, \mathrm{CuSO}_{4} \cdot 5 \mathrm{H}_{2} \mathrm{O} 0.57 \mathrm{~g} / \mathrm{L}$, $\mathrm{Co}\left(\mathrm{NO}_{3}\right)_{2} \cdot 6 \mathrm{H}_{2} \mathrm{O} 0.49 \mathrm{~g} / \mathrm{L}, \mathrm{Na}_{2}$ EDTA $\cdot 2 \mathrm{H}_{2} \mathrm{O}$. Compressed air was delivered continuously at $250 \mathrm{~L} / \mathrm{h}$ from the bottom of the reactor upward to avoid settling of algae, ensure the homogeneity in the entire reactor volume and introduce $\mathrm{CO}_{2}$ to the culture. The temperature was maintained at $22.0 \pm 2.0{ }^{\circ} \mathrm{C}$. The algal biomass was cultivated in nutrient-supplemented tap water for 15 days. Algae biomass (composed of $70 \%$ of Chlorella sp. and $30 \%$ of Scenedesmus sp.) was harvesting by preliminary sedimentation followed by centrifugation (3000 rpm for $6 \mathrm{~min}$ ). Any pretreatment method of harvested biomass was used before anaerobic digestion.

\section{Feedstock}

The substrates containing microalgae biomass (MB) and silage of Sida (SS) at a ratio of 100:0\% VS (MB100), $80: 20 \% \quad$ VS $\quad(M B 80+$ SS20), 60:40\% VS (MB60 + SS40), 40:60\% VS (MB40 + SS60), 20:80\% VS (MB20 + SS80), 0:100\% VS (SS100) were used as a feedstock for biogas production. The characteristics of SS, $\mathrm{MB}$ as well as all the substrates used are presented in Table 1.

\section{Anaerobic Digestion Experiments}

The $5 \mathrm{~L}$ full-mixing anaerobic reactors New Brunswick Bioflo 310 (Eppendorf, USA) with 4 L working volume were used. The temperature in the reactors was maintained at $35{ }^{\circ} \mathrm{C}$. The anaerobic sludge which was an inoculum for anaerobic reactors originated from the closed fermentation tanks of a local municipal wastewater treatment plant (Table 2). The concentration of total solids (TS) seeded into the reactors was $4.0 \mathrm{~g} \mathrm{TS} / \mathrm{L}$. The reactors were loaded with inoculum $(100 \% \mathrm{v} / \mathrm{v})$ and then the feedstock was continuously added. After the continuous start-up period 
Table 1 Feedstock characteristics (mean $\pm \mathrm{SD}$ )

\begin{tabular}{|c|c|c|c|c|}
\hline Parameter & Unit & MB100 & MB80 + SS20 & $\mathrm{MB} 60+\mathrm{SS} 40$ \\
\hline Total solids & $\%$ & $10.40 \pm 1.49$ & $15.81 \pm 1.73$ & $21.21 \pm 1.98$ \\
\hline Volatile solids & $\% \mathrm{TS}$ & $87.69 \pm 1.06$ & $85.58 \pm 1.14$ & $83.46 \pm 1.22$ \\
\hline $\mathrm{TN}$ & $\mathrm{mg} / \mathrm{g} \mathrm{TS}$ & $45.97 \pm 3.92$ & $37.33 \pm 3.32$ & $28.70 \pm 2.73$ \\
\hline $\mathrm{TP}$ & $\mathrm{mg} / \mathrm{g} \mathrm{TS}$ & $4.36 \pm 0.94$ & $3.57 \pm 0.79$ & $2.78 \pm 0.64$ \\
\hline $\mathrm{TC}$ & $\mathrm{mg} / \mathrm{g} \mathrm{TS}$ & $463.82 \pm 25.31$ & $458.95 \pm 23.81$ & $454.08 \pm 22.32$ \\
\hline TOC & $\mathrm{mg} / \mathrm{g} \mathrm{TS}$ & $437.26 \pm 19.77$ & $429.35 \pm 20.10$ & $421.44 \pm 20.44$ \\
\hline $\mathrm{C}: \mathrm{N}$ & - & $9.51 \pm 0.43$ & $11.50 \pm 4.33$ & $14.69 \pm 8.24$ \\
\hline $\mathrm{pH}$ & - & $8.06 \pm 0.76$ & $8.00 \pm 0.72$ & $7.92 \pm 0.69$ \\
\hline Proteins & $\% \mathrm{TS}$ & $28.73 \pm 2.45$ & $23.33 \pm 2.08$ & $17.93 \pm 1.71$ \\
\hline Lipids & $\% \mathrm{TS}$ & $19.96 \pm 1.39$ & $16.15 \pm 1.14$ & $12.35 \pm 0.89$ \\
\hline Saccharides & $\% \mathrm{TS}$ & $15.84 \pm 2.55$ & $21.31 \pm 2.99$ & $26.78 \pm 3.44$ \\
\hline Parameter & Unit & $\mathrm{MB} 40+\mathrm{SS} 60$ & $\mathrm{MB} 20+\mathrm{SS} 80$ & SS100 \\
\hline Total solids & $\%$ & $26.62 \pm 2.22$ & $32.02 \pm 2.47$ & $37.43 \pm 2.71$ \\
\hline Volatile solids & $\% \mathrm{TS}$ & $81.35 \pm 1.30$ & $79.23 \pm 1.38$ & $77.12 \pm 1.46$ \\
\hline $\mathrm{TN}$ & $\mathrm{mg} / \mathrm{g} \mathrm{TS}$ & $20.06 \pm 2.13$ & $11.43 \pm 1.54$ & $2.79 \pm 0.94$ \\
\hline $\mathrm{TP}$ & $\mathrm{mg} / \mathrm{g} \mathrm{TS}$ & $1.99 \pm 0.49$ & $1.20 \pm 0.34$ & $0.41 \pm 0.19$ \\
\hline $\mathrm{TC}$ & $\mathrm{mg} / \mathrm{g} \mathrm{TS}$ & $449.20 \pm 20.82$ & $444.33 \pm 19.33$ & $439.46 \pm 17.83$ \\
\hline TOC & $\mathrm{mg} / \mathrm{g}$ TS & $413.54 \pm 20.77$ & $405.63 \pm 21.11$ & $397.72 \pm 21.44$ \\
\hline $\mathrm{C}: \mathrm{N}$ & - & $20.61 \pm 12.14$ & $35.50 \pm 16.05$ & $142.55 \pm 19.95$ \\
\hline $\mathrm{pH}$ & - & $7.80 \pm 0.65$ & $7.60 \pm 0.62$ & $7.24 \pm 0.58$ \\
\hline Proteins & $\% \mathrm{TS}$ & $12.54 \pm 1.33$ & $7.14 \pm 0.96$ & $1.74 \pm 0.59$ \\
\hline Lipids & $\% \mathrm{TS}$ & $8.54 \pm 0.63$ & $4.74 \pm 0.38$ & $0.93 \pm 0.13$ \\
\hline Saccharides & $\% \mathrm{TS}$ & $32.25 \pm 3.88$ & $37.72 \pm 4.33$ & $43.19 \pm 4.77$ \\
\hline
\end{tabular}

Table 2 Characteristics of anaerobic sludge used as an inoculum of anaerobic reactors (mean $\pm \mathrm{SD}$ )

\begin{tabular}{llc}
\hline Parameter & Unit & \multicolumn{1}{l}{ Value } \\
\hline Total solids & $\%$ & $3.60 \pm 0.21$ \\
Volatile solids & $\%$ TS & $68.46 \pm 2.53$ \\
TN & $\mathrm{mg} / \mathrm{g} \mathrm{TS}$ & $33.08 \pm 3.35$ \\
TP & $\mathrm{mg} / \mathrm{g} \mathrm{TS}$ & $1.66 \pm 0.23$ \\
TC & $\mathrm{mg} / \mathrm{g} \mathrm{TS}$ & $309.05 \pm 28.37$ \\
TOC & $\mathrm{mg} / \mathrm{g} \mathrm{TS}$ & $199.42 \pm 34.29$ \\
$\mathrm{C} / \mathrm{N}$ ratio & - & $9.34 \pm 0.08$ \\
$\mathrm{pH}$ & - & $7.21 \pm 0.32$ \\
\hline
\end{tabular}

(40 days of the complete replacement of the reactor volume), the reactors were operated at a constant HRT of 40 days, while the OLR was maintained at the level of $2.0 \mathrm{~g} \mathrm{VS} / \mathrm{L}$ day. The reactors worked continuously for 80 days. Before anaerobic digestion, all the substrates were hydrated to about $90 \%$. The characteristics of the hydrated feedstock are given in Table 3 . The samples for analyses were taken every 2 days.

\section{Analytical Methods}

The microalgae species identification was carried out based on non-solid or semi-solid preparations at microscope magnifications of: $1.25 \times 10 \times 40$ or $1.25 \times 10 \times 100$. Once collected and fixed with a $4.0 \%$ formalin solution with the addition of ethyl alcohol, the samples were concentrated via sedimentation to the volume that enabled determining at least 10 and not more than 25-30 specimens of phytoplanktonic algae in one visual field of the microscope at the magnification of $500 \times$.

The contents of total solids (TS) and volatile solids (VS) in the feedstock, anaerobic sludge and digestates were determined according to the gravimetric method. Samples dried at $105{ }^{\circ} \mathrm{C}$ were also assayed for contents of total carbon (TC), total organic carbon (TOC) and total nitrogen (TN) with the use of elementary particle size analyzer (Flash 2000, Thermo Scientific, USA). Total phosphorus (TP) and sugar content (saccharides) were determined using a spectrophotometer DR 2800 (HACH Lange, Germany). The content of total protein was estimated by multiplying the value of TN by 6.25 . The concentration of lipids was assayed by Soxhlet method using an extractor 
Table 3 The characteristics of the hydrated feedstock dosed to the reactors

\begin{tabular}{llllll}
\hline $\begin{array}{l}\text { Algae mass } \\
\text { culture (g/day) }\end{array}$ & $\begin{array}{l}\text { Sida mass } \\
(\mathrm{g} / \text { day) }\end{array}$ & $\begin{array}{l}\text { Hydration of the } \\
\text { substrate }(\%)\end{array}$ & $\begin{array}{l}\text { Amount of water for } \\
\text { hydration }(\mathrm{mL} / \text { day })\end{array}$ & $\begin{array}{l}\text { Sample volume dosed to the } \\
\text { reactors (mL/day) }\end{array}$ & $\begin{array}{l}\text { Hydration of the substrate after } \\
\text { addition of water }(\%)\end{array}$ \\
\hline 87.72 & 0 & 89.60 & 15.70 & 100 & 90.90 \\
70.17 & 5.54 & 84.19 & 31.20 & 100 & 90.65 \\
52.63 & 11.08 & 78.79 & 44.10 & 100 & 90.42 \\
35.01 & 16.63 & 73.38 & 56.20 & 100 & 90.17 \\
17.54 & 22.17 & 67.98 & 70.60 & 100 & 89.91 \\
0 & 27.71 & 62.57 & 82.70 & 100 & 89.63 \\
\hline
\end{tabular}

(B-811 Büchi, Switzerland). The $\mathrm{pH}$ of aqueous solutions of homogenized feedstock (10 g biomass mixed in $50 \mathrm{~mL}$ deionized water) was determined with a pH-meter $(1000 \mathrm{~L}$, VWR, Germany).

Biogas flow rate was measured continuously using the digital gas flow meters XFM17S (Aalborg Instruments \& Controls, Inc., USA). The composition of biogas produced was measured every $24 \mathrm{~h}$ using a gastight syringe $(20 \mathrm{~mL}$ injection volume) and a gas chromatograph (GC, 7890A Agilent, USA) equipped with a thermal conductivity detector (TCD). The GC was fitted with the two Hayesep Q columns (80/100 mesh), two molecular sieve columns (60/ 80 mesh) and Porapak Q column (80/100) operating at a temperature of $70{ }^{\circ} \mathrm{C}$. The temperatures of the injection and detector ports were 150 and $250{ }^{\circ} \mathrm{C}$, respectively. Helium and argon were used as the carrier gases at a flow of $15 \mathrm{~mL} / \mathrm{min}$.

The results were processed statistically with the Statistica 10.0 PL package (StatSoft, Inc.). The hypothesis on the distribution of each analyzed variable was verified based on the Shapiro-Wilk W test. One-way analysis of variance (ANOVA) was conducted to determine the significance of differences between the variables. The homogeneity of variance in groups was tested with Levene's test, whereas Tukey's RIR test was used to determine the significance of differences between the analyzed variables. In all tests, differences were considered significant at $p=0.05$.

\section{Results and Discussion}

\section{Characteristics of Feedstock Used for Anaerobic Digestion}

The differences in concentration of the feedstock's components are given in Table 1. The total solids (TS) of the silage of Sida (SS) were greater than the microalgae biomass (MB); thus mixing SS with MB decreased TS of the feedstock, but VS was almost at the same level. High lipid concentration of about $20 \%$ TS was noted in the MS biomass, while SS feedstock contained less than $1 \%$ of lipids.
The main difference was in $\mathrm{TN}$ concentration in biomass which affected the $\mathrm{C} / \mathrm{N}$ ratio. Generally, adding $\mathrm{MB}$ to SS had a positive effect on $\mathrm{C} / \mathrm{N}$ ratio decreasing from 142.55 to 11.50 . MB had the highest concentration of proteins of $28.73 \%$ TS and low $\mathrm{C} / \mathrm{N}$ ratio of 9.51 . In contrast, $\mathrm{SS}$ was characterized by low protein content $(1.74 \% \mathrm{TS})$ and high $\mathrm{C} / \mathrm{N}$ ratio of 142.55 . Adding $\mathrm{MB}$ to $\mathrm{SS}$ decreased $\mathrm{C} / \mathrm{N}$ ratio which ranged from 35.50 when the proportion of $\mathrm{MB}$ was $20 \%$ (MB20 + SS80) to 11.50 when MB constituted $80 \%$ of the substrate (MB80 + SS20).

High $\mathrm{C} / \mathrm{N}$ ratio of Sida was not comparable with the data provided by other researchers. The silage of Sida harvested in a similar growing stage was characterized by $\mathrm{C} / \mathrm{N}$ ratio of 22.43 (Oleszek et al. 2013) or 29.8 (Pokój et al. 2015). Because no fertilizers were used for Sida cultivation, low nitrogen concentration in harvested biomass could be attributed to nitrogen limitation in soil (Jablonowski et al. 2016).

Jablonowski et al. (2016) showed that the first cut of Sida in June at a development stage of BBCH-Sida 55 displayed a TS content of $20 \%$, while in our study it was $37.43 \%$. However, silaging contributes to increasing VS and TS contents over time.

Algal biomass characteristics depend on the species, growth phase, environmental conditions, nutrient supply, culture conditions, and harvesting/processing techniques (Gonzalez Fernandez et al. 2012; Wang and Park 2015). In our study, the MB characteristics were set in the typical range reported in the literature, where microalgae contained $18-46 \%$ carbohydrate, $12-48 \%$ lipids, and $18-60 \%$ proteins (Tibbetts et al. 2015). In algae biomass, the value of $\mathrm{C} / \mathrm{N}$ ratio was generally below 10 (Ward et al. 2014).

\section{Biogas/Methane Production Rate and Yield from the Substrates}

The impact of mixing SS with MB consisting of Chlorella sp. (70\%) and Scenedesmus sp. (30\%) on biogas/methane potential was assessed in mesophilic anaerobic digestion experiments lasting 40 days. The results showed that the volumetric biogas/methane production rates (VBPR/ 
VMPR) and biogas/methane yield were the highest for MB40 + SS60. The average values of VBPR and VMPR were, respectively, $4756.15 \pm 105.94$ and $2815.03 \pm$ $175.52 \mathrm{~mL} /$ day, while the biogas/methane yield was $594.52 \pm 13.24 / 351.88 \pm 25.21 \mathrm{~mL} / \mathrm{g}$ VS (Figs. 1, 2). Similar VMPR and methane yields $(p>0.05)$ were achieved in the series MB60 + SS40. The addition of more (above 60\%) or less (below 40\%) MB to SS reduced the efficiency of methane production $(p<0.05)$, but there were no differences $(p>0.05)$ noted in the series MB80 + SS20 and MB20 + SS80, and also when only MB was digested (Figs. 1,2). During AD of SS as a sole substrate, VMPR and methane yields were the lowest $(p<0.05)$, though VBPR and the biogas yields were relatively high.

The methane content in biogas was the highest (over $60 \%$ ) during anaerobic co-digestion of SS, with the proportion of $\mathrm{MB}$ ranging $60-80 \%$ similarly to that for a sole MB (MB100), $(p>0.05)$, (Fig. 3). The lower content of $\mathrm{MB}$ in the feedstock decreased the percentage methane content in biogas below 60\% $(p<0.05)$, and the lowest value was observed for Sida feedstock (SS100).

There was a strong correlation between the $\mathrm{C} / \mathrm{N}$ ratio and methane content in biogas $\left(r^{2}=0.9937\right)$, (Fig. 3). The $\mathrm{C} / \mathrm{N}$ ratio also highly affected $\left(r^{2}=0.8244\right)$ the methane production and yield (Figs. 1, 2). In turn, the variation of biogas production was not heavily dependent on the value of the $\mathrm{C} / \mathrm{N}$ ratio $\left(r^{2}=0.5985\right)$, (Figs. 1,2$)$.

It is well known, that the composition of the feedstock added to anaerobic reactors has a significant impact on the growth rate of anaerobic bacteria, and consequently on the biogas production. Our study showed that excess of nitrogen in $\mathrm{MB}(\mathrm{C} / \mathrm{N}$ of 9.51$)$ decreased biogas potential less than the deficiency of nitrogen in SS (C/N of 142.55). Biogas yield of MB as a sole feedstock achieved the same level as during co-digestion of SS with MB in the proportions of $20 \% \mathrm{SS}$ and $80 \% \mathrm{MB}(\mathrm{C} / \mathrm{N}$ of 11.50$)$, as well as $80 \%$ SS and $20 \% \mathrm{MB}(\mathrm{C} / \mathrm{N}$ of 35.50$),(p>0.05)$. Higher biogas yield of MB than SS can be attributed to the absence

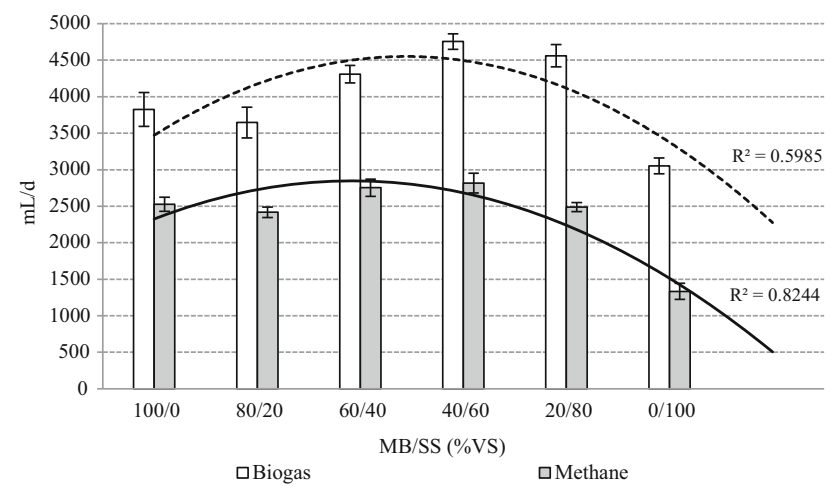

Fig. 1 Volumetric biogas/methane production rate

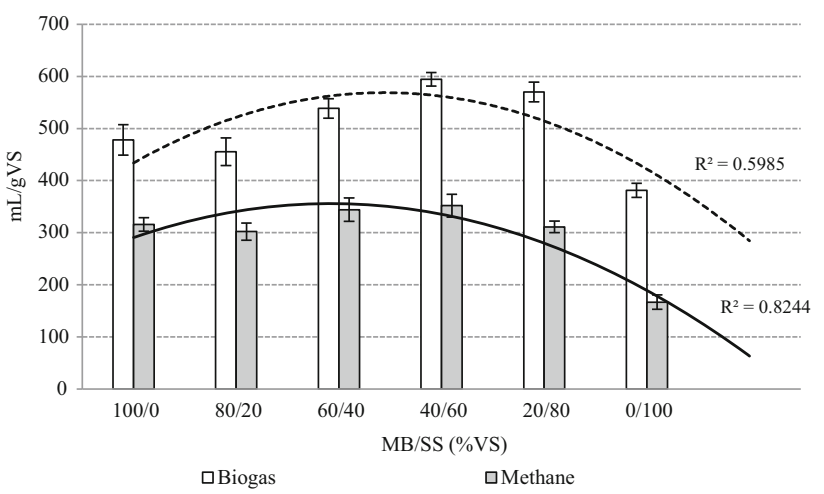

Fig. 2 Biogas/methane yield

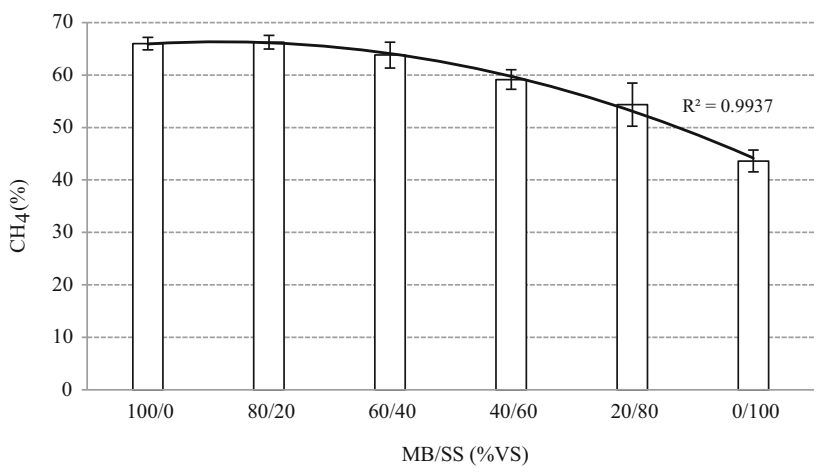

Fig. 3 Methane content in biogas

of lignin and low cellulose content, which decrease organic matter conversion to biogas (Zhong et al. 2012). Moreover, MB was characterized by higher lipid content, which provides higher biogas yield of $1014 \mathrm{~L} / \mathrm{kg} \mathrm{VS}$ fed $(\mathrm{STP}, 273 \mathrm{~K}$, $101.3 \mathrm{kPa})$ than carbohydrates $\left(415 \mathrm{~L} / \mathrm{kg} \mathrm{VS}_{\text {fed }}, \mathrm{STP}\right.$, $273 \mathrm{~K}, 101.3 \mathrm{kPa}$ ), (Wang and Park 2015). Our results also suggested the positive effects of protein biodegradation on alkalinity inside the anaerobic digester to maintain $\mathrm{AD}$ process stability. According to Demirel and Scherer (2009), nutritional deficiencies and insufficient alkalinity in energy crops may lead to AD process imbalance.

First attempts with biogas batch tests showed high biogas/methane potential of Sida (harvested in July, 6th year of growing), which, respectively, reached $435 / 220 \mathrm{NmL} / \mathrm{g}$ VS (Oleszek et al. 2013). It was similar to our results of biogas and methane production of 381.39 and $166.61 \mathrm{~mL} / \mathrm{g}$ VS, respectively. Jablonowski et al. (2016) achieved a biogas yield of $419.5 \mathrm{~L} / \mathrm{kg}$ VS with methane concentration of 53.5\% from the silage of Sida at the development stage of BBCH-Sida 55. In turn, the yield of methane production from the microalgae biomass may reach $240-307 \mathrm{~mL} / \mathrm{g}$ VS for Chlorella vulgaris and $210-261 \mathrm{~mL} / \mathrm{g}$ VS for Scenedesmus sp. (Ras et al. 2011; Zamalloa et al. 2012; Roberts et al. 2016), which was similar to our findings of $315.71 \mathrm{~mL} / \mathrm{g}$ VS for the substrate consisting of Chlorella sp. and Scenedesmus sp. 
Table 4 Digestate characteristics (mean $\pm \mathrm{SD}$ )

\begin{tabular}{|c|c|c|c|c|}
\hline Parameter & Unit & MB100 & $\mathrm{MB} 80+\mathrm{SS} 20$ & $\mathrm{MB} 60+\mathrm{SS} 40$ \\
\hline VS reduction & $\%$ & 24.60 & 21.15 & 15.10 \\
\hline $\mathrm{TN}$ & $\mathrm{mg} / \mathrm{g} \mathrm{TS}$ & $41.87 \pm 3.58$ & $33.02 \pm 1.24$ & $26.28 \pm 3.06$ \\
\hline $\mathrm{TP}$ & $\mathrm{mg} / \mathrm{g} \mathrm{TS}$ & $4.12 \pm 1.06$ & $3.61 \pm 0.65$ & $2.03 \pm 1.01$ \\
\hline $\mathrm{TC}$ reduction & $\%$ & 27.55 & 17.60 & 15.49 \\
\hline TOC reduction & $\%$ & 31.43 & 26.67 & 25.06 \\
\hline $\mathrm{C}: \mathrm{N}$ & - & 7.16 & 9.53 & 12.02 \\
\hline $\mathrm{pH}$ & - & $7.29 \pm 0.12$ & $6.86 \pm 0.40$ & $6.71 \pm 0.18$ \\
\hline Proteins & $\% \mathrm{TS}$ & $27.92 \pm 32.16$ & $21.14 \pm 0.77$ & $17.05 \pm 1.91$ \\
\hline Lipids & $\% \mathrm{TS}$ & $2.72 \pm 0.79$ & $4.16 \pm 1.06$ & $6.06 \pm 0.83$ \\
\hline Saccharides & $\% \mathrm{TS}$ & $1.76 \pm 0.40$ & $2.01 \pm 0.75$ & $1.76 \pm 0.51$ \\
\hline Parameter & Unit & $\mathrm{MB} 40+\mathrm{SS} 60$ & $\mathrm{MB} 20+\mathrm{SS} 80$ & SS100 \\
\hline VS reduction & $\%$ & 24.78 & 18.06 & 14.95 \\
\hline $\mathrm{TN}$ & $\mathrm{mg} / \mathrm{g} \mathrm{TS}$ & $19.06 \pm 3.43$ & $10.66 \pm 2.06$ & $2.26 \pm 1.37$ \\
\hline $\mathrm{TP}$ & $\mathrm{mg} / \mathrm{g} \mathrm{TS}$ & $1.11 \pm 0.16$ & $0.92 \pm 0.38$ & $0.44 \pm 0.13$ \\
\hline $\mathrm{TC}$ reduction & $\%$ & 30.74 & 29.78 & 26.90 \\
\hline TOC reduction & $\%$ & 21.16 & 28.71 & 22.26 \\
\hline$C: N$ & - & 17.10 & 27.13 & 136.81 \\
\hline $\mathrm{pH}$ & - & $7.19 \pm 0.21$ & $7.01 \pm 0.28$ & $6.73 \pm 0.36$ \\
\hline Proteins & $\% \mathrm{TS}$ & $13.54 \pm 2.14$ & $7.41 \pm 1.29$ & $1.44 \pm 0.85$ \\
\hline Lipids & $\% \mathrm{TS}$ & $1.41 \pm 0.25$ & $1.68 \pm 0.72$ & $0.68 \pm 0.42$ \\
\hline Saccharides & $\% \mathrm{TS}$ & $1.07 \pm 0.33$ & $2.11 \pm 0.17$ & $1.09 \pm 0.42$ \\
\hline
\end{tabular}

The positive synergy effects observed in co-digestion due to the balancing of parameters in the co-substrate mixture may offer a potential for higher methane yields (Mata-Alvarez et al. 2000; Schwede et al. 2013). In our study, co-digestion of energy crop Sida with microalgae biomass improved biogas and methane production. The best results were achieved at $\mathrm{MB} / \mathrm{SS}$ ratio of 0.66 $(\mathrm{MB} 40+\mathrm{SS} 60)$ and $1.5(\mathrm{MB} 60+\mathrm{SS} 40)$, while the $\mathrm{C} / \mathrm{N}$ ratio was, respectively, 14.69 and 20.61. Under these conditions, the biogas/methane production ranged from $538.66 / 344.19$ to $594.52 / 351.88 \mathrm{~mL} / \mathrm{g}$ VS.

Co-digestion of microalgae biomass with low $\mathrm{C} / \mathrm{N}$ ratio with carbon-rich energy crops has been reported previously. Corn straw and algae biomass were used as the codigestion substrates for biogas production by Peng et al. (2012). They achieved significantly higher biogas yield (687.3 mL/g VS, $63.3 \%$ methane in biogas) in the co-digestion process compared to that using only corn stalk or algae biomass when the ratio of corn stalk, algae biomass and sludge was 2:8:1. Zhong et al. (2012) observed that the co-digestion process of algae and corn straw at $\mathrm{C} / \mathrm{N}$ ratio of 20/1 increased methane yield by $62 \%$ at $325 \mathrm{~mL} / \mathrm{g} \mathrm{VS}$ (approx. $600 \mathrm{~mL}$ biogas/g VS). Microalgae biomass addition to corn silage with a ratio of $1 / 6$ increased biogas yield by about $9 \%$ to $660 \mathrm{~m}^{3} / \mathrm{kg}$ VS compared to the monodigested crop feedstock (Schwede et al. 2013). However, there are no published data on co-digestion of Sida (Sida hermaphrodita) energy crop with microalgae biomass. Our results suggest that the co-digestion process led to a balanced nutrient composition of the feedstock, consequently increasing the biogas/methane productivity during AD.

\section{Digestates Characteristics}

The residual substrates in post-fermented solids were evaluated (Table 4). The protein concentration in the digestates was comparable with that of the undigested biomass. However, the utilization of saccharides and lipids was almost complete with all feedstock tested. Decreases in the $\mathrm{C} / \mathrm{N}$ ratio of all digestates was noted as a result of using carbon compounds (the content of TC, TOC, saccharides decreased in solids); however, the level of TN was nearly unaffected. No significant drop in $\mathrm{pH}$ was noticed in the post-fermented solids, which was still in the optimum range ( $\mathrm{pH}$ 6.5-8.0) for methanogenesis. The TC and TOC content in the solid fraction decreased after AD. TOC reduction ranged from $25.06 \%$ in $\mathrm{MB} 60+\mathrm{SS} 40$ to $31.43 \%$ in MB100. Reduction of volatile solids (VS) during the overall digestion process with methane production was the highest in MB100 as well as MB40 + SS60, and reached over $24 \%$. The relatively low efficiency of anaerobic biodegradation of MB, SS and the substrates consisting of $\mathrm{MB}$ and $\mathrm{SS}$ indicated that the hydrolysis of the biomass was the limiting step; thus it should be considered 
to improve the digestibility of algae biomass and energy crop Sida hermaphrodita using pretreatment methods.

\section{Conclusion}

In this work, microalgae biomass consisting of Chlorella sp. and Scenedesmus sp. was co-digested with the silage of Sida (Sida hermaphrodita) in semi-continuous experiments under mesophilic anaerobic conditions. The results showed that mixing of silage of Sida with microalgae biomass ensured a more balanced $\mathrm{C} / \mathrm{N}$ ratio with less inhibition and digester imbalance. The best results were achieved when the microalgae biomass constituted 40 and $60 \%$ of the substrate, and the $\mathrm{C} / \mathrm{N}$ ratio was, respectively, 14.69 and 20.61 . The $\mathrm{C} / \mathrm{N}$ ratio strongly affected the methane content in biogas $\left(r^{2}=0.9937\right)$ as well as the methane production and yield $\left(r^{2}=0.8244\right)$. The co-digestion process improved biogas/methane production to the level of $594.52 / 351.88 \mathrm{~mL} / \mathrm{g}$ VS.

Acknowledgements This work was supported by the Programme Innovative Economy within the framework of the European Regional Development Fund as a part of the Key Project No. POIG.01.01.0200-016/08, entitled: Model agro-energy complexes as an example of distributed cogeneration based on local and renewable energy sources. It was also supported by the University of Warmia and Mazury in Olsztyn No. 18.610.008-300.

Open Access This article is distributed under the terms of the Creative Commons Attribution 4.0 International License (http://crea tivecommons.org/licenses/by/4.0/), which permits unrestricted use, distribution, and reproduction in any medium, provided you give appropriate credit to the original author(s) and the source, provide a link to the Creative Commons license, and indicate if changes were made.

\section{References}

Barbosa DBP, Nabel M, Jablonowski ND (2014) Biogas-digestate as nutrient source for biomass production of Sida hermaphrodita, Zea mays L. and Medicago sativa L. Energy Procedia 59:120-126. doi:10.1016/j.egypro.2014.10.357

Borkowska H, Molas R (2012) Two extremely different crops, Salix and Sida, as sources of renewable bioenergy. Biomass Bioenerg 36:234-240. doi:10.1016/j.biombioe.2011.10.025

Borkowska H, Molas R (2013) Yield comparison of four lignocellulosic perennial energy crop species. Biomass Bioenergy 51:145-153. doi:10.1016/j.biombioe.2013.01.017

Borkowska H, Wardzińska K (2003) Some effects of Sida hermaphrodita R. cultivation on sewage sludge. Pol J Environ Stud 12:119-122

Chinnasamy S, Bhatnagar A, Claxton R, Das KC (2010) Biomass and bioenergy production potential of microalgae consortium in open and closed bioreactors using untreated carpet industry effluent as growth medium. Bioresour Technol 101:6751-6760. doi:10. 1016/j.biortech.2010.03.094

Chynoweth DP, Turick CE, Owens JM, Jerger DE, Peck MW (1993) Biochemical methane potential of biomass and waste feedstocks.
Biomass Bioenerg 5:95-111. doi:10.1016/0961-9534(93)900102

Dębowski M, Zieliński M, Grala A, Dudek M (2013) Algae biomass as an alternative substrate in biogas production technologiesreview. Renew Sust Energ Rev 27:596-604. doi:10.1016/j.rser. 2013.07.029

Demirel B, Scherer P (2009) Bio-methanization of energy crops through mono-digestion for continuous production of renewable biogas. Renew Energy 34:2940-2945. doi:10.1016/j.renene. 2009.05.013

Esposito G, Frunzo L, Panico A, Pirozzi F (2012) Enhanced biomethane production from co-digestion of different organic wastes. Environ Technol 33:2733-2740. doi:10.1080/ 09593330.2012.676077

Gonzalez Fernandez MC, Sialve B, Bernet N, Steyer JP (2012) Impact of microalgae characteristics on their conversion to biofuel. Part II: focus on biomethane production. Biofuel Bioprod Biorefining 6:205-218. doi:10.1002/bbb.337

Güsewell S (2004) N:P ratios in terrestrial plants: variation and functional significance. New Phytol 164:243-266. doi:10.1111/j. 1469-8137.2004.01192.x

Jablonowski ND, Kollmann T, Nabel M, Damm T, Klose H, Müller M, Bläsing M, Seebold S, Krafft S, Kuperjans I, Dahmen M, Schurr U (2016) Valorization of Sida (Sida hermaphrodita) biomass for multiple energy purposes. Glob Change Biol Bioenergy. doi:10.1111/gcbb.12346

Jankowski KJ, Dubis B, Budzyński WS, Bórawski P, Bułkowska K (2016) Energy efficiency of crops grown for biogas production in a large-scale farm in Poland. Energy 109:277-286. doi:10.1016/ j.energy.2016.04.087

Mata-Alvarez J, Macé S, Llabrés P (2000) Anaerobic digestion of organic solid wastes. An overview of research achievements and perspectives. Bioresour Technol 74:3-16. doi:10.1016/S09608524(00)00023-7

Montingelli ME, Tedesco S, Olabi AG (2015) Biogas production from algal biomass: a review. Renew Sust Energy Rev 43:961-972. doi:10.1016/j.rser.2014.11.052

Nabel M, Temperton VM, Poorter H, Lücke A, Jablonowski ND (2016) Energizing marginal soils-the establishment of the energy crop Sida hermaphrodita as dependent on digestate fertilization, NPK, and legume intercropping. Biomass Bioenergy 87:9-16. doi:10.1016/j.biombioe.2016.02.010

Oleszek M, Matyka M, Lalak J, Tys J, Paprota E (2013) Characterization of Sida hermaphrodita as a feedstock for anaerobic digestion process. J Food Agric Environ 11:1839-1841

Parkin GF, Owen WF (1986) Fundamentals of anaerobic digestion of wastewater sludges. J Environ Eng (ASCE) 112:867-920. doi:10.1061/(ASCE)0733-9372(1986)112:5(867)

Peng Y, Niklas KJ, Sun S (2011) The relationship between relative growth rate and whole-plant $\mathrm{C}: \mathrm{N}: \mathrm{P}$ stoichiometry in plant seedlings grown under nutrient-enriched conditions. J Plant Ecol UK 4:147-156. doi:10.1093/jpe/rtq026

Peng SC, Hou CH, Wang J, Chen TH, Liu XM, Yue ZB (2012) Performance of anaerobic co-digestion of corn straw and algae biomass from lake Chaohu. Trans Chin Soc Agric Eng 28:173-178. doi:10.3969/j.issn.1002-6819.2012.15.028

Pienkos P, Darzins A (2009) The promise and challenges of microalgal-derived biofuels. Biofuel Bioprod Biorefining 3:431-440. doi:10.1002/bbb.159

Pokój T, Bułkowska K, Gusiatin ZM, Klimiue E, Jankowski KJ (2015) Semi-continuous anaerobic digestion of different silage crops: VFAs formation, methane yield from fiber and non-fiber components and digestate composition. Bioresour Technol 190:201-210. doi:10.1016/j.biortech.2015.04.060

Ras M, Lardon L, Bruno S, Bernet N, Steyer JP (2011) Experimental study on a coupled process of production and anaerobic digestion 
of Chlorella vulgaris. Bioresour Technol 102:200-206. doi:10. 1016/j.biortech.2010.06.146

Roberts KP, Heaven S, Banks CJ (2016) Comparative testing of energy yields from micro-algal biomass cultures processed via anaerobic digestion. Renew Energy 87:744-753. doi:10.1016/j. renene.2015.11.009

Schwede S, Kowalczyk A, Gerber M, Span R (2013) Anaerobic codigestion of the marine microalga Nannochloropsis salina with energy crops. Bioresour Technol 148:428-435. doi:10.1016/j. biortech.2013.08.157

Tibbetts SM, Milley JE, Lall SP (2015) Chemical composition and nutritional properties of freshwater and marine microalgal biomass cultured in photobioreactors. J Appl Phycol 27:1109-1119. doi:10.1007/s10811-014-0428-x

To JP, Zhu J, Benfey PN, Elich T (2010) Optimizing root system architecture in biofuel crops for sustainable energy production and soil carbon sequestration. Biol Rep 2:65. doi:10.3410/B2-65

Wang M, Park C (2015) Investigation of anaerobic digestion of Chlorella sp. and Micractinium sp. grown in high-nitrogen wastewater and their co-digestion with waste activated sludge.
Biomass Bioenergy 80:30-37. doi:10.1016/j.biombioe.2015.04. 028

Ward AJ, Lewis DM, Green FB (2014) Anaerobic digestion of algae biomass: a review. Algal Res 5:204-214. doi:10.1016/j.algal. 2014.02.001

Wu X, Yao W, Zhu J, Miller C (2010) Biogas and CH(4) productivity by co-digesting swine manure with three crop residues as an external carbon source. Bioresour Technol 101:4042-4047. doi:10.1016/j.biortech.2010.01.052

Yen HW, Brune DE (2007) Anaerobic co-digestion of algal sludge and waste paper to produce methane. Bioresour Technol 98:130-134. doi:10.1016/j.biortech.2005.11.010

Zamalloa C, Boon N, Verstraete W (2012) Anaerobic digestibility of Scenedesmus obliquus and Phaeodactylum tricornutum under mesophilic and thermophilic conditions. Appl Energy 92:733-738. doi:10.1016/j.apenergy.2011.08.017

Zhong W, Zhongzhi Z, Yijing L, Wei Q, Meng X, Min Z (2012) Biogas productivity by co-digesting Taihu blue algae with corn straw as an external carbon source State Key. Bioresour Technol 114:281-286. doi:10.1016/j.biortech.2012.02.111 